\title{
Súkromné archívy na Slovensku
}

História starostlivosti štátu o archívne dokumenty sa začala písat' na Slovensku vydaním vládneho nariadenia č. 29/1954 Zb. z. o archívnictve. Do spoločenských zmien v roku 1989, sa činnost' archívov na Slovensku zameriavala na odbornú správu archívnych dokumentov, ktoré vznikli z pôsobností štátnych úradov a samospráv, škôl, štátnych podnikov, družstiev a pod. Sústava archívov pozostávala z riadiacej zložky Ministerstva vnútra Slovenskej republiky - Archívnej správy, či neskôr z odboru archívov a spisovej služby, zo Štátneho ústredného archívu v Bratislave, Archívu hlavného mesta Bratislava a Archívu mesta Košice, nasledovalo 7 štátnych oblastných archívov a 38 štátnych okresných archívov. Spoločenské zmeny po 17. novembri 1989 výrazne zasiahli aj do režimu fungovania štátnych archívov.

V súčasnosti (2014) môžeme na Slovensku archívy rozdelit' na:

1. Verejné archívy:

a) Štátne ústredné archívy (Slovenský národný archív, Štátny ústredný banský archív) a štátne archívy s regionálnou územnou pôsobnost'ou (Štátny archív v Banskej Bystrici s pobočkami; Štátny archív v Bratislave s pobočkami; Štátny archív v Bytči s pobočkami; Štátny archív v Košiciach s pobočkami; Štátny archív v Levoči s pobočkami, Štátny archív v Nitre s pobočkami, Štátny archív v Prešove s pobočkami);

b) archívy štátnych orgánov, štátnych rozpočtových organizácií a štátnych príspevkových organizácií;

c) mestské archívy a archívy samosprávnych krajov;

d) archívy právnických osôb zriadených zákonom;

e) archívy právnických osôb a archívy fyzických osôb, ktoré sú orgánmi verejnej správy. 
2. Súkromné archívy: archívy právnických osôb a archívy fyzických osôb ${ }^{1}$.

1. Verejné archívy spravujú fondy súkromných osôb, rodín a rodov, ktoré majú pre spoločnost' väčší význam. Ide hlavne o osoby z politického, kultúrneho, spoločenského, či športového diania. V Slovenskom národnom archíve v Bratislave sa nachádzajú fondy viacerých šlachtický rodov a panstiev, napr. rody Erdödy (1216) 1247-1894; Esterházi 1236-1939; Habsburg 1728-1918; rodín a osôb - hudobného skladatel'a a tvorcu prvej slovenskej opery Kováč Wieland Ján Levoslav Bella 1861-1943; rímskokatolíckeho kňaza, slovenského politika a zakladatel'a Slovenskej l'udovej strany Andreja Hlinku 1836-1938; významného slovenského politika, astronóma a vedca Milana Rastislava Štefánika 1849-1938; historika a archivára Pavla Križka 1254-1943; politika, verejného činitel'a Vavra Šrobára 1900-1948. V Štátnom ústrednom banskom archíve sa nachádzajú pozostalosti, či osobné fondy rôznych odborníkov v baníctve, ale i príbuzných odborov. Napr. Osobný fond bývalého riaditel'a archívu Jozefa Gindla, CSc. (1925) 1927-1991, Kolomana Münnicha 1875-1934 a Ing. Alexandra Valentényiho 1876-1946.

Súkromné archívy významných osôb v príslušnom regióne sa naSlovensku sústred'ovali hlavne $\mathrm{v}$ štátnych archívoch, $\mathrm{v}$ menšej miere $\mathrm{v}$ ich pobočkách. Zväčša išlo o osobné prianie tej ktorej rodiny o zachovanie súkromného archívu v menšom archíve s ktorým ich spájali osobné kontakty. V Štátnom archíve v Banskej Bystrici môžeme nájst' fondy rodov, ktoré pôsobili v tomto regióne od 13. do 19. storočia. Zaujímavými sú napr. rody Koháry-Coburg (1241) 1321-1909, rod Szontágh 1844 a Turóczi z Radnoviec 1631-1944. V Śtátnom archíve $v$ Bratislave sú početnejšie zastúpené fondy rodín a osôb, čo vyplýva z postavenia Bratislavy ako hlavného mesta a sústred'ovania významných činovníkov v tomto regióne. Sú tu napr. fondy šlachtickej rodiny Andrássy 1764-1912, Križko (1531) 1547-1846, Mednyánszky z Beckova (1263) 1323-1934. Početne zastúpené sú archívy rodov v Štátnom archíve v Bytči od 14. storočia do roku 1940. Informácie o významných politických, cirkevných, hospodárskych a kultúrnych dejatel'och z regiónu severozápadného Slovenska sa nachádza skoro v stovke archívnych fondov rodín a osôb od 13. do 20. storočia. Významnými sú fondy prof. Ing. Petra Halašu 1698-1950, prof. Dr. Antona Bagina 1650-1982 a prof. Jaroslava Vodrážku, ktorý sa preslávil hlavne knižnou ilustráciou. Štátny archív v Košiciach spravuje fond rodu Dessewffyovcov z Fintíc 1808-1861 a písomností niekol'ko desiatok rodín a osobností z územia východného Slovenska z rokov 1549-1990. Štátny archív v Levoči sa špecializuje na rody a panstvá z historického územia Spišskej župy. Nachádzajú sa tu napr. archívy rodov Andrássy z Krásnej Hôrky 1290-1948, Hohenlohe

\footnotetext{
${ }^{1}$ Zákon č. 395/2002 z. z. o archívoch a registratúrach a o doplnení niektorých zákonov.
} 
z Javoriny 1829-1937, Horváth - Stansith zo Strážok (1294) 1298-1973, VáradySzakmáry z Lučivnej 1570-1906. Od 13. storočia do roku 1990 majú zachované archívne dokumenty z okolo 80 súkromných archívov. Mimoriadny význam má fond lekára a röntgenológa Dr. Vojtecha Alexandra a jeho rodiny (1635) 1703-1975. Štátny archív $v$ Nitre sa zameriava na archívne fondy rodov a panstiev zo západného Slovenska. Významný archívny fond je fond rodu Pálfi v Bojniciach (1370) 1614-1949 a Bat'ov vel'kostatok v Bojniciach 1926-1949. Štátny archív v Prešove má tiež pomerne bohaté zastúpenie archívnych fondov rodov, ktoré mali svoje majetky na východnom Slovensku, najmä v historickej Šarišskej župe - napr. Rod Berzeviczy z Brezovice (1209) 1567-1943. Vo fonde sa zachovali archívne dokumenty torzovito, prevažne išlo o korešpondenciu a literárnu pozostalost' príslušníkov rodu. Zaujímavý je aj archív rodu Sztáray z Michaloviec (1057) 1279-1931. Sztárayovci boli dlhšiu dobu dedičnými županmi Užhorodskej župy. Po Drugethovskom panstve boli ich majetky druhé najväčšie na východnom Slovensku.

Z pobočiek štátnych archívov spomeňme aspoň niektoré, ktorým sa podarilo zachovat' vzácne súkromné zbierky. Ide hlavne o majetkové dokumenty, korešpondenciu, časti knižničnej a fotografickej pozostalosti. V Štátnom archíve v Banskej Bystrici, pobočka Banská Bystrica sa nachádza fond rodiny Gregussovcov z Banskej Štiavnice. Pobočka vo Zvolene spravuje hudobnú pozostalost' rodiny Ostrolúckej 1785-1853. V Štátnom archíve v Bytči, pobočka Čadca je archív Rodiny Slaninákovcov - Škrabákovcov z Rakovej 1675-1932. V pobočke v Martine sa nachádza vzácny fond národného umelca maliara Martina Benku 1939-1967, či mešt'anostu Galandu z rokov 1710-1875. Viacero osobných fondov spravuje pobočka v Žiline. Nachádzajú sa tu napríklad fondy rodiny Závodských zo Závodia 1351-1888, Vojtecha Tvrdého 1911-1947, Pavla Hložného 1931-1944 a Františka Bednárika 1925-1951. V Štátnom archíve v Levoči, pobočka Poprad spravujú archívny fond lekára Dr. Michala Greisigera zo Spišskej Belej, partizána Daniela Vrbičana z Popradu, novinára Pavla Svetoňa z Popradu, či športovca Vladimíra Jančeka z Kežmarku. V pobočke v Spišskej Novej Vsi sú uložené písomnosti G.A. Illiny von Illenfeld zo Smolníka (1787) 1831 a Reich zo Spišskej Novej Vsi 1895-1950. V Štátnom archíve Košice, pobočka Rožňava je sprístupnený fond rodu Gömöry z Rožňavy (1493) 1803-1894 a Szontágh z Rožňavy 1870-1918. V pobočke v Trebišove sa nachádza archív rodu Mailáthovcov z Príbeníka 1806-1867. Viac súkromných fondov sa nachádza v Štátnom archíve v Bratislave, pobočka Trenčín. Nachádzajú sa tu napríklad písomnosti Jozefa Braneckého (1868) 1893-1962 (1992), Ing. Eugena Schotlza 1878-1918 a PhMr. Jána Halaša (1876) 1937-1981.

Špeciálne postavenie majú mestské archívy v Bratislave a v Košiciach. V archíve hlavného mesta Bratislavy sa nachádza viacero mimoriadne vzácnych osobných fondov. Pre Slovákov majú mimoriadny význam pozostalosti Michala Miloslava Hodžu 1811-1870 a Jozefa Miloslava Hurbana 1817-1888, ktorí pat- 
rili medzi blízkych priatel’ov a spolupracovníkov slovenského národného buditel'a Ĺudovíta Štúra. Tu má uložené písomnosti aj F. S. Messerschmidt 1732-1783, považovaný za jedného z najväčších karikaturistov z obdobia baroka. V Bratislave patrí medzi výrazné osobnosti aj sochár Viktor Tilgner, ktorý je autorom viacerých diel nachádzajúcich sa v Bratislave. Zachovali sa jeho písomnosti z rokov 1844-1896. Pre poznanie politického vývoja Európy a hlavne Francúzska má vel'ký význam osobný fond Jozefa Alexandra Hübnera $\mathrm{z}$ rokov 1811-1892. Tento pracoval v rokoch 1833-1837 v Metternichovej kancelárii, neskôr sa na cisárskom dvore zúčastňoval všetkých diplomatických rokovaní. Najcennejším súkromným fondom Archívu mesta Košíc je fond Král Ján Zápol'ský. V archíve sa zachovalo 5 registrov obsahujúcich súpisy královských šiat, šperkov, drahokamov, pečatí, konských zlatých ozdôb, zoznamy odoslaných alebo prijatých darov, vyúčtovanie dôchodkov rozličných častí Uhorska a Sedmohradska, vyúčtovanie výdavkov a pod.

Zvláštnu skupinu tvoria špecializované verejné archívy. Z hl'adiska našej témy sú mimoriadne dôležité - Archív literatúry a umenia Slovenskej národnej knižnice v Martine a Archív Matice slovenskej v Martine. Oba archívy plnia úlohy ústredného archívu literatúry a umenia Slovenskej republiky so zretel'om na prednostné získavanie, odborné spracovanie, ochranu, skúmanie a publikovanie literárnoarchívnych, hudobnoarchívnych a fotografických pamiatok týkajúcich sa osobností slovenskej kultúrnej histórie od najstarších čias po súčasnost'. V archívoch sa nachádzajú literárne rukopisy a pozostalosti slovenských spisovatel'ov a národných dejatel'ov najmä z 19. a 20. storočia. Fondy obsahujú i množstvo jednotlivín - rukopisov literárnych diel, korešpondenciu, dokumentárny materiál k dejinám vedy, literatúry a kultúry. Špeciálnymi položkami sú hudobné rukopisy a hudobniny, v ktorých nájdeme bohaté zbierky l'udových piesní od viacerých pôvodcov a zberatel'ov, písomné pozostalosti a osobné archívy skladatel'ov a interpretov. V archívoch sa nachádzajú aj bohaté zbierky fotografií.

V Ústrednom archíve Slovenskej akadémie vied v Bratislave sa nachádzajú osobné fondy vedeckých osobností Slovenskej akadémie vied a Českej akadémie vied. Obdobne fondy sú v Bratislave v Archíve Univerzity Komenského, Archívu Slovenskej technickej univerzity, Archívu Ekonomickej univerzity. Početné množstvo osobných fondov hlavne z 19. a 20. storočia sa nachádza v Archive Slovenského národného múzea v Bratislave.

V Archíve výtvarného umenia Slovenskej národnej galérie sa nachádza viacero pozostalostí. Významné postavenie pre rôznorodost' materiálov má fond Jána Fadrusza, bratislavského sochára, žijúceho na prelome 19. a 20. storočia. Jedinečný je i osobný fond maliara 19. Storočia Cyrila Kutlíka, zakladatel'a umeleckej školy v Belehrade. O osobnosti a diele maliara Ladislava Medňanského vel'a napovie pozostalost' rodiny Medňanských, ktorej súčastou sú i známe mad’arské denníky písané gréckou abecedou. Nie menej vý- 
znamné sú osobné fondy takých osobností slovenského výtvarného umenia, akými boli Jozef Hanula, Peter Július Kern, Ján Koniarek a iní. Významné miesto majú aj jednotliviny sochára Viktora Tilgnera či listy Alojza Riegeleho. Najvýznamnejšou jednotlivinou je umelecký program zachytený v listoch Mikuláša Galandu a Ĺudovíta Fullu. Široké spektrum pohl'adov na výtvarné umenie poskytujú vedecké práce, recenzie, hodnotenia v osobných archívoch historikov umenia Alžbety Güntherovej - Mayerovej, Vojtecha Tilkovského atd'. Z fondov architektov sú obsahovo vel'mi bohaté fondy Szonyi, Harminc, Belluš a Svetlík.

V bratislavských archívoch - v Archíve Pamiatkového úradu SR, Archíve Slovenského rozhlasu a televízie, Národnom filmovom archíve Slovenského filmového ústavu, Archívu divadelného ústavu sú sústredené hlavne pozostalosti pracovníkov a významných osobností v danom odbore. Rovnako je to aj v Archíve Mincovne Kremnica, š.p. ${ }^{2}$

Spracovaniu osobných fondov sa $\mathrm{v}$ štátnych archívoch nevenovala mimoriadna pozornost'. Pokyny na ich spracovanie sa nachádzajú v publikácii Ochrana, sprístupňovanie a využívanie archívnych dokumentov, ktoré vydala Archívna správa Ministerstva vnútra SSR v roku $1988^{3}$. V metodike sa venujú spôsobu inventarizovania osobných dokladov, osobnej korešpondencie a rukopisov, vedeckých, literárnych a iných prác, verejných prejavov, denníkov, pamätí a pod. Špeciálne metodické usmernenie pre spracovanie osobných fondov ministerstvo nevydalo.

Mnohí archivári zo štátnych archívov pracujú na obecných monografiách a biografických publikáciách. Na základe osobného kontaktu s obyvatel'mi miest a obcí sa im darí zachraňovat' osobné fondy a aj písomností mnohých organizácií, najmä spolkov a združení, čo je vel'mi dôležité aj pri biografickom výskume. Zároveň archivári nepriamo zaškol'ujú obyvatel'ov v archivárskej práci, ale aj v tom, ako sa s písomnostami súkromného charakteru nakladá. Po výjdení monografií obyvatelia vidia praktický význam takejto práce. Osobné kontakty neraz zachránili bez finančných nákladov pre štát vzácne archívne dokumenty.

Odlišná situácia vznikla pri skupine súkromných archívov, ktoré „de facto" do roku 1989 na Slovensku neexistovali. Po zmene vlastníckych vzt'ahov vznikla v Slovenskej republike aj kategória: 2. Súkromné archívy - archívy

2 Z. Kollárová, J. Hanus, Sprievodca po slovenských archívoch, Prešov: UNIVERSUM 1999, s. 94; Informatívny sprievodca štátnych archívov Slovenskej republiky I, red. M. Stieberová, Bratislava: Ministerstvo vnútra Slovenskej republiky 2000, s. 215; Informatívny sprievodca štátnych archívov Slovenskej republiky II/1, red. M. Mišovič, Bratislava: Ministerstvo vnútra Slovenskej republiky 2001, s. 359; Informatívny sprievodca štátnych archívov Slovenskej republiky II/2, red. M. Mišovič, Bratislava: Ministerstvo vnútra Slovenskej republiky 2001, s. 352.

${ }^{3}$ V. Horváth, P. Kartous, J. Watzka, Ochrana, sprístupňovanie a využívanie archívnych dokumentov, Bratislava: Archívna správa Ministerstva vnútra SSR 1988, s. 77-82. 
právnických osôb a archívy fyzických osôb. Štátne archívy nad'alej spravujú vyššie uvedené osobné a rodinné fondy.

V 90. rokoch narástla potreba urýchlene preberat' do archívov písomností zaniknutých inštitúcii, štátnych podnikov, spoločenských organizácii, ktorých vyrad'ovanie prebiehalo $\mathrm{v}$ časovej tiesni a často neodborne. To zapríčinilo prírastky písomností bez formálnej či obsahovej hodnoty ${ }^{4}$. Kapacita archívov sa naplnila a nebolo možné zabezpečit' kompletizáciu d'alších archívnych fondov. Bolo nutné prenajímat' nie vždy archívnym podmienkach vyhovujúce priestory. Na rôznych fórach sa začala diskusia, ako a akým spôsobom zamedzit' prírastkom nearchívnej povahy, ako dosiahnut', aby sa do archívu dostali len dokumenty archívnej hodnoty. Okolo roku 1993 sa v archívnej verejnosti ozvali hlasy uvažujúce o potrebe akéhosi medziarchívu, ktorý bude zabezpečovat' medzičlánok, v ktorom sa uložia dokumenty pokial' im neuplynú lehoty uloženia a to v prípade, že pôvodca ukončil svoju činnost', zo zákona, likvidáciou, konkurzom, bankrotom ${ }^{5}$.

Po službe ukladat' dokumenty nearchívnej povahy nastal dopyt a trh reagoval ponukou. Svoju činnost' v tejto oblasti postupne začali ponúkat' už v roku 1991 spoločnosti s ručením obmedzeným, ktoré vznikali najprv, ako uložiská pre jeden zaniknutý podnik, no postupne si získavali svoju klientelu na základe ponúkaných služieb. Podobne to postupovalo aj v prípade fyzických osôb, kde na živnostenskom úrade bolo možné ohlásit' živnost' na správu registratúry ${ }^{6}$.

Výrazný pokrok v riešení problému so zabezpečením odbornej správy registratúrnych záznamov nearchívnej povahy nastal prijatím zákona SNR č. 395/2002 Z. z., v ktorom sa v \$23 hovorí o správe registratúry inou osobou. Odsek 1) vymedzuje, že pôvodca registratúry môže zverit' inej osobe správu registratúrnych záznamov, ktoré už nepotrebuje a ktorým ešte neuplynula lehota uloženia. V odseku 2) je určené, že správu registratúry iného pôvodcu registratúry môže vykonávat' len osoba, ktorá má úplné stredné vzdelanie a najmenej tri roky praxe v odbore. Odsek 3) stanovuje, že povinnosti pôvodcu registratúry, ktorému sú záznamy spravované ostávajú zachované a správca je plne zodpovedný v rámci poskytovania svojej služby.

Každý subjekt, ktorý sa venuje správe registratúry sa musí riadit' nasledovnými zákonnými normami: Zákonom č. 395/2002 o archívoch a registratúrach a o doplnení niektorých zákonov - úplné znenie, Vyhláškou Ministerstva vnútra Slovenskej republiky č. 628/2002 Zb. z. o doplnení niektorých zákonov $\mathrm{v}$ znení neskorších predpisov. $\mathrm{V}$ súčasnosti sa pripravuje nový zákon o archívoch a registratúrach.

\footnotetext{
${ }^{4}$ SLOBODA, Elo. Archívy a skartácia. In Fórum archivárov, 1993, roč. IV., č. 4-5, s. 15.

5 Tamtéž.

${ }^{6}$ www.nikol.sk.
} 
V roku 2004 bolo v obchodnom registri v Slovenskej republike registrovaných asi 3200 firiem s predmetom činnosti súvisiacim s úschovou záznamov. V súčasnosti má takýto predmet podnikania okolo 500 - 700 firiem, z ktorých aktívne vykonáva túto činnost' asi 40. Dnes už môžeme konštatovat', že mnohé tak ako rýchlo vznikli, rýchlo aj zanikli a spolu s nimi niekedy u nich uložené záznamy...

Na Slovensku podnikanie v oblasti spravovania písomnosti iných organizácií je vol'nou živnost'ou. Nie je viazané na povolenie Ministerstva vnútra SR. Ich činnost' je kontrolovaná štátnymi archívmi podl'a územnej príslušnosti.

Po viacerých rokoch hl'adania sa spomenutých firiem môžeme skonštatovat', že v súčasnosti by sme ich mohli rozdelit' podl'a činnosti nasledovne:

1. Spoločnosti so zahraničnou účastou- cielene sa venujú správe písomných dokumentov a ich uloženiu. K svojej činnosti využívajú patričné softwarové vybavenie (napr. nemecká softvérová spoločnost' HABEL) a sú aj iniciátormi takejto činnosti. Okrem toho sa venujú aj iným činnostiam, ktoré podporujú správu registratúry. Niekedy je to aj opačne - správa registratúry je doplnkovou činnost'ou iných služieb pre spotrebitel'ov.

2. Slovenské firmy, resp. spoločnosti, ktorých hlavná náplň je správa a úschova registratúrnych záznamov. Títo sa seriózne venujú písomnostiam mnohých firiem a organizácií, majú kvalitné materiálne a personálne vybavenie.

3. Jednotlivci, ktorí spravujú písomnosti jednej firmy. Spravidla ide o horšie materiálne a personálne zabezpečenie. Zdíhavé je vybavovanie požiadaviek obyvatel'ov.

4. Fyzické osoby, ktoré zabezpečujú samotný výkon odbornej správy záznamov, ktoré sú uložené u pôvodcu. Pôvodca si písomnosti ukladá vo svojom registratúrnom stredisku.

Náplňou činnosti všetkých uvedených skupín je vytváranie príslušných smerníc na spravovanie písomností (registratúrny plán, registratúrny poriadok), zabezpečenie pravidelného vyrad'ovania a kvalifikovanej manipulácie s písomnost'ami. Okrem fyzických osôb, ostatné spomenuté subjekty zabezpečujú vhodné priestory, vyškolený personál, snažia sa o dobrú dostupnost' informácií. Pracovníci zabraňujú neorganizovanému vyrad'ovaniu písomnej agendy. Spoločnosti so zahraničnou účast'ou a slovenské firmy vykonávajú v spomenutej oblasti bohatú školiacu činnost'. Správa registratúry sa postupne vo firmách zlepšuje aj vd’aka tomu, že jednou z podmienok na získanie certifikátu kvality ISO je zabezpečenie rešpektovania zákonných noriem týkajúcich sa správy písomností. Firmy sprostredkúvajú kontakt s príslušným štátnym archívom a zabezpečujú odovzdanie archívnych dokumentov po vyrad'ovacom konaní $\mathrm{v}$ určenej lehote do štátneho archívu. 
Môžeme uviest' niekol'ko firiem dlhodobejšie úspešne pôsobiacich na Slovensku:

Medzi najstaršie patrí Konzorcium DOCUGROUP, NovéZámky. Spravuje registratúru svojich partnerov v Slovenskej republike, Českej republike, Mad'arskej republike, Holandskom král'ovstve. Má komplexne vybudovanú infraštruktúru, vysokokvalifikovaných odborníkov a skúsenosti nadobudnuté v správe registratúry od roku 1991. Na základe softvérového vybavenia a organizácii práce sa elektronické obrazy záznamov v priebehu niekol'kých minút dostanú na monitor žiadatel'a. Systém súčasne vyhodnocuje či má žiadatel' povolený prístup $\mathrm{k}$ požadovanej informácii. $\mathrm{V}$ zriedkavých prípadoch vyžiadania originálov je čas doručenia limitovaný možnostáami doručovacej služby. Firma zabezpečí kompletný vyrad'ovací proces vrátane komunikácie so štátnym archívom, následne vykoná ${ }^{7}$ odbornú likvidáciu vyradených záznamov pri dodržaní všetkých opatrení zabraňujúcich úniku informácií.

Firma Nikol Martin s.r.o., v Martine pôsobí na trhu už od roku 1993.Zaoberá sa vývojom a dodávkou technológii pre uskladnenie a archivovanie registratúrnych záznamov. Spočiatku bola jej nosným prvkom výroba a dodávka regálových systémov pre archívy a registratúrne strediská. Od roku 2000 rozšírila ponuku o správu registratúry a miesto uloženia záznamov nearchívnej povahy pre iné organizácie, ktorým poskytuje vlastný program na správu registratúry NEO Manager. Vo svojej ponuke má i archívne boxy v rôznych rozmeroch. Poskytuje outsourcing v oblasti správy registratúry ${ }^{8}$.

F.M. Servis, spol. s r. o., Bratislava svojím klientom umožňuje uschovávat' dokumenty a médiá s najvyšším stupňom dlhodobej ochrany. Vznikla v roku 1999, jej služby dlhodobo využívajú slovenské firmy i spoločnosti s európskou až celosvetovou pôsobnost'ou - z mnohých oblastí hospodárskej činnosti. Všetky dáta vznikajúce $\mathrm{v}$ spoločnosti v súvislosti s dlhodobou správou listinných dokumentov ako aj digitalizáciou ukladajú v zabezpečenom dátovom úložisku. Dátové úložisko F.M. Servisu spol. s r. o. svojou štruktúrou garantuje minimálnu možnost' straty dát, ich prípadné zneužitie a umožňuje svojim klientom on-line prístup k databáze, resp. konkrétnym dokumentom, uschovanej registratúry z akéhokol'vek miesta /online cez Internet/ cez zabezpečený prístup a prácu $\mathrm{s}$ ňou. $\mathrm{V}$ súčasnosti sa $\mathrm{v}$ dátovom úložisku $\mathrm{F}$. M. Servis spravuje okolo 17000000 klientských dát ${ }^{9}$.

Viacero slovenských firiem špecializujúcich sa na správu registratúry združuje Asociácia správcov registratúr. Vznikla okolo roku 2005. Špecializuje sa na poradenskú činnosté. V roku 2012 získala akreditáciu na vzdelávacie programy v oblasti správy registratúr a archívnej činnosti.

\footnotetext{
${ }^{7}$ www.docugroup.sk.

${ }^{8}$ www.nikol.sk.

${ }^{9}$ www.fmservis.sk.
} 
Medzi spomenutými pozitívami činnosti firiem zaoberajúcich sa správou písomností je aj viacero úskalí s ktorými sa stretávajú pracovníci štátnych archívov. Najväčším nebezpečenstvom je to, že medzi písomnost'ami bez archívnej hodnoty, ktoré majú spravovat' spomenuté firmy sa nachádzajú aj písomnosti skupiny s archívnou hodnotou. Vo firmách, ktoré spravujú málo fondov, zväčša iba jeden, sa stáva, že dostupnost' k informáciám nie je dobrá a písomnosti sú tu iba „nečinne“ uložené. Problematickým je zrušenie firmy a presun ňou spravovaných dokumentov na d'alšie subjekty. Sporná je aj ochrana osobných údajov.

Nájst' rovnováhu medzi prácou štátnych archívov a súkromným sektorom, či medzi štátnou správou písomností a ich súkromným spravovaním je niekedy pomerne náročné. Pomer medzi chápaním duchovného princípu, kultúrneho a historického dedičstva s pomerom financií je vel'mi krehká mierka. Optimálnym princípom je vzájomná spolupráca a vzájomná úcta k práci tých druhých. Veríme, že časom vzniknú presné kritéria pre správu písomností pre oba sektory a zo štátnych archívov a spoločností zaoberajúcich sa správou registratúry sa spoločne stanú záchrancovia našej minulosti i prítomnosti.

Súkromným archívom na Slovensku sa venuje aj Slovenská genealogicko-heraldická spoločnost' so sídlom v Martine. Ciel'om jej činnosti od roku 1991 je poskytnút základné informácie o možnostiach a podmienkach genealogického výskumu na Slovensku. Spravidla raz ročne v septembri organizuje neformálne stretnutia a odborné školenia pre začínajúcich i pokročilých genealógov. K najúspešnejším patrili seminár Ústne pramene a techniky genealogického výskumu (Martin 1995) a dva ročníky Letnej školy praktickej genealógie (Martin 1996, 1997), tematicky zamerané na štúdium v archívoch SR i v slovacikálnom zahraničí. V roku 2001 spoločnost' vydala pomôcku na čítanie starých rukopisov - Paleografickú čítanku. V roku 1997 spoločnost' vytvorila slovenskú verziu programu Brother’s Keeper pre Windows, ktorý umožňuje archivovanie genealogických dát. Od roku 1992 organizovala projekt Prepis náhrobných nápisov, ktorého ciel'om je vytvorit' počítačovo spracovanú databázu údajov z náhrobníkov. Spoločnost' sa podiel'ala aj na projekte výskumu genealógií rodín slovenskej evanjelickej inteligencie 19. storočia, ktorého výsledkom by mal byt' lexikón s genealógiami asi 300 rodín. Čiastkové výstupy boli publikované prevažne na stránkach časopisu Genealogickoheraldický hlas a zborníka Biografické štúdie, ktoré vydáva Biografický ústav Matice slovenskej. Od roku 2001 spolupracuje na výchovno-vzdelávacom projekte Poznaj vlastnú minulost' alebo pátranie po predkoch, ktorý je určený žiakom základných a stredných škôl. Každé 3 roky organizuje sút’až Najlepšie genealogické práce spojenú s verejným vyhodnocovaním prác amatérskych i profesionálnych genealógov ${ }^{10}$.

${ }^{10}$ www.genealogy-heraldry.sk/slo/gp.html, 15 stycznia 2015 r. 
Zuzana Kollárová

Marta Bednárová

\title{
Archiwa prywatne na Słowacji
}

\section{Streszczenie}

Autorki zwracają uwagę na fakt, iż w systemie słowackich archiwów archiwa i archiwalia prywatne odgrywają coraz większą rolę. Omawiają także strukturę archiwów słowackich i ich prawne usytuowanie oraz najważniejsze, najciekawsze materiały o charakterze spuścizn, wskazując jednocześnie na ich możliwości badawcze.

\section{Private Archives in Slovakia}

\begin{abstract}
The author points out the fact that in the Slovak archival system, archives and private archival materials are gaining more importance. She also discusses the structure of the Slovak archives, their legal situation, and the most important, most interesting legacies, emphasizing their research potential.
\end{abstract}

